Journal of Applied Business, Taxation and Economics Research (JABTER)

Vol. 1, No. 1, 2021 (Page: 31-37)

DOI : https://doi.org/10.54408/jabter.v1i1.4

E-ISSN 2808-263X

\title{
Liability Payment System at PT. Indonesia Power PLTU Banten 2 Labuan OMU
}

\author{
Wiwin Widiawati ${ }^{1^{*}}$ \\ ${ }^{1}$ University of Sultan Ageng Tirtayasa, Indonesia \\ 455wiwin@gmail.com ${ }^{1 *}$
}

Keywords : Liability Payments.

\begin{abstract}
:
The purpose of writing this thesis report is to determine the liability payment system and factors that are obstacles in the payment system of liabilities at PT. Indonesia Power PLTU Banten 2 Labuan OMU. The object of this thesis is the liability at PT. Indonesia Power PLTU Banten 2 Labuan OMU. The writing method used is the interview method and the documentation method. The type of data used is primary data and secondary data. Sources of data obtained from direct research and literature studies. How to collect data through observation, interviews, and documentation. The results of the study that the payment system used at PT. Indonesia Power PLTU Banten 2 Labuan OMU using Cash Management Bank / BNI Direct. The obstacle that occurs at the time of payment of a liability is poor cash management.
\end{abstract}




\section{Introduction}

A company is an organization founded by a person, group, or other entity whose activities are to produce and distribute to meet human economic needs. The main goal of the company is to achieve profit in order to achieve its goals. (Soemarso, 2010: 22)

In carrying out its activities the company uses its own capital. In addition to its own capital, the company also cannot be separated from debt. Debt can also be used to minimize the company's financial deficit by fulfilling the company's operational activities such as buying materials for production and sales using credit purchases and having to make payments at a later date. Nurachman (2018:1)

PT Indonesia Power PLTU Banten 2 Labuan OMU as a company in Indonesia which is engaged in the power generation business, in terms of recording, presenting and classifying accounting in the processing of the company's trade payables on accounting policies in accordance with the rules determined by the applicable Financial Accounting Standards. In the implementation of the settlement of trade payables at PT Indonesia Power PLTU Banren 2 Labuan OMU using an accrual basis system where in the event of a purchase transaction or service project of a credit nature, a trade payable will arise which must be paid when it is due, this trade payable is recognized if there has been a billing in the form of an invoice where the request for billing for the procurement of material goods has been received or the service work project has been completed.

In practice, trade payables are recorded and reported at their nominal value, because current liabilities only involve a short term (less than one year), so there is no big difference between the present value of trade payables and their value at maturity. This is because this debt mainly comes from the purchase of merchandise that is traded on a daily basis, or the purchase of raw materials in industrial companies (Samryn, 2015: 108). Accounts payable is derived from the purchase of goods or services to be used in the company's operations or to purchase inventory (Warren 2016:543).

There were total debt payments in 2016, 2017 and 2018. In 2016 the debt was Rp. $7,120,147,010$ but in 2017 the debt increased by Rp. 19,748,985,175 due to the purchase of materials by PT. Indonesia Power PLTU Banten 2 Labuan OMU. In 2018 debt from 2017 to 2018 decreased by Rp. 22,596,198,785 due to the procurement of service work. Changes in debt will definitely not be the same because debt depends on work activities in the unit.

The effect of the debt on the company is that it has a good impact because sometimes debt can be a solution to meet the company's operational needs or increase the company's capital.

Based on the description above, the authors are interested in reviewing further and trying to discuss it in the final project entitled "Liability Payment System at PT. Indonesia Power PLTU Banten 2 Labuan Omu"

\section{Research Method}

1. Data Type

According to Sugiyono (2010), seen from the data source, it is divided into two, namely primary data and secondary data obtained or collected by researchers directly from the data 
source, while secondary data is data obtained or collected by researchers from various existing sources.

a. Primary data

This data is in the form of information and explanations related to research and obtained by conducting interviews with employees from the finance department of PT. Indonesia Power PLTU Banten 2 Labuan OMU. The data obtained is the general description of the company, the accounting policies used by the company, as well as the application and the system used.

b. Data secondary

This data is in the form of documents obtained from the company and also in the form of sources related to the problems studied.

2. Data source

The data collected in this study came from various data sources, namely:

a. Primary data sources come from field interviews conducted with respondents

b. Secondary data sources come from the publication of various literatures in several places such as the library of the Faculty of Economics and Business UNTIRTA.

\section{Method of collecting data}

There are two methods used in collecting the final project data, namely:

1. Interview method

Interview is a form of communication between two or more people that involves someone who wants to get information from someone else by asking questions, based on a specific purpose. Interviews were conducted to obtain related information regarding Lability payments at PT. Indonesia Power PLTU Banten 2 Labuan OMU and interviews were conducted with several employees in the finance department who became sources of information.

2. Documentation method

Documentation is to collect written materials, how much data is obtained by PT. Indonesia Power PLTU Banten 2 Labuan OMU with the aim of completing additional research data and to obtain information that supports data analysis such as company profiler, organizational structure, job description, company vision and mission, operational standards, company history.

\section{Results and Discussion}

1. How is the liability payment system used at PT. Indonesia Power PLTU Banten 2 Labuan OMU?

The system used at PT. Indonesia Power is a cash management bank or BNI Direct. This BNI Direct service is a transaction service with an internet banking platform, specifically for work units that require real-time and online cash management solutions. The convenience of using BNI Direct, namely:

Easy to access

Easy registration 
Easy to use

Operates 24 hours a day and 7 days a week

Equipped with a security system.

The differences between Theory and PT. Indonesia Power PLTU Banten 2 Labuan $\mathrm{OMU}$ can be seen in table 4.9 below.

Table 1. Comparison between Theory and PT. Indonesia Power PLTU Banten 2 Labuan OMU

\begin{tabular}{cc}
\hline No Information & Theory \\
& PT. Indonesia Power PLTU \\
Banten 2 Labuan OMU
\end{tabular}

\begin{tabular}{|c|c|c|c|}
\hline $\begin{array}{ll}1 & \text { Liability } \\
& \text { payment } \\
& \text { procedures }\end{array}$ & $\begin{array}{l}\text { according to Romney } \\
\text { and Steinbart (2012:398) } \\
\text { the expenditure cycle is: } \\
\text { 1. Order goods and } \\
\text { services } \\
\text { 2. Receipt of goods } \\
\text { and services of } \\
\text { 3. Approval from } \\
\text { invoices suppliers } \\
\text { 4. payment }\end{array}$ & $\begin{array}{l}9 . \\
10 . \\
11 .\end{array}$ & $\begin{array}{l}\text { Vendors enter invoices } \\
\text { Receive documents for } \\
\text { payment of verified debts } \\
\text { and prepare payment } \\
\text { vouchers. } \\
\text { Check payments } \\
\text { according to the debt } \\
\text { payment plan that has } \\
\text { been made. } \\
\text { Entering into the payment } \\
\text { system, namely: bilyet } \\
\text { giro, check, cash, } \\
\text { (taken/transferred) } \\
\text { ERP or } \\
\text { The bill will be checked by } \\
\text { the tax implementer } \\
\text { The tax implementer will } \\
\text { submit the imposition of } \\
\text { VAT and PPH taxes } \\
\text { After being validated then } \\
\text { the file is submitted to the } \\
\text { financial sps } \\
\text { Administration manager } \\
\text { for verification and } \\
\text { signature on the billing file } \\
\text { Proof of cash out } \\
\text { Make a payment } \\
\text { Posting in the ERP system } \\
\text { and also the BNI bank } \\
\text { application. }\end{array}$ \\
\hline
\end{tabular}




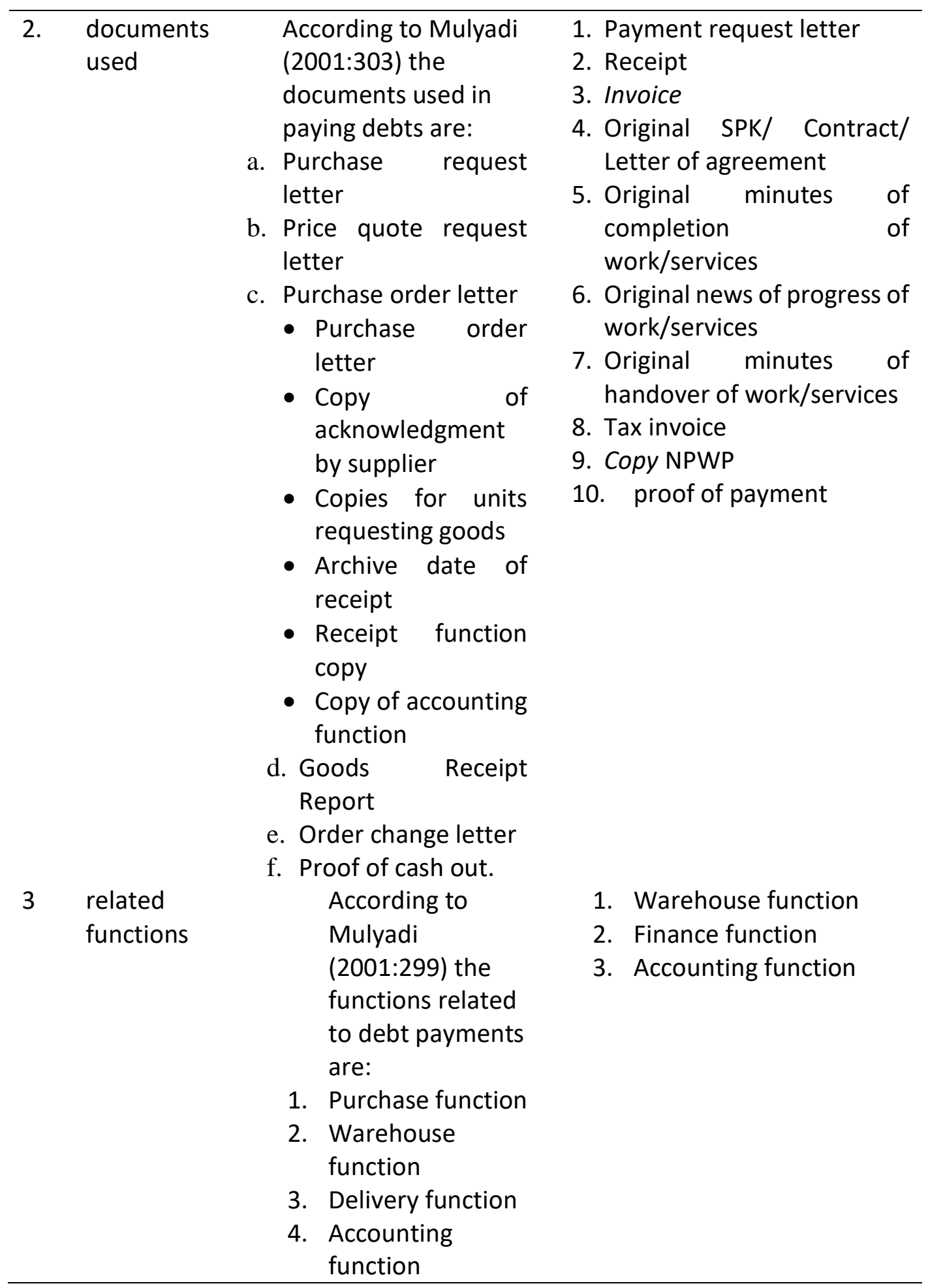

There are differences in the liability payment procedure according to Mulyadi's theory and the liability payment procedure according to PT. Indonesia Power PLTU Banten 2 Labuan. According to Romney and Steinbart, there are 4 parts, while according to PT. Indonesia Power PLTU Banten 2 Labuan OMU there are 11 stages. Starting with the vendor section entering the bill then the completeness of the billing file is checked by the document verification check section after being checked and if the billing file is in accordance with what is recommended then the document 
verification section will submit the bill to the ERP. From the ERP then the bill will be checked for tax by the tax executor then the tax executor will submit the VAT \& PPH tax, after the tax section is validated, the physical file is submitted to the financial SPs,

2. To find out what are the obstacles in the liability payment system at PT. Indonesia Power PLTU Banten 2 Labuan OMU ?

Many companies face obstacles in the liability payment system, the following are the obstacles that occur in paying liabilities, namely: Not making a careful plan, if starting a company by borrowing capital from other parties it is normal but the loan cannot be done arbitrarily but the company bad cash management, if bad cash management can be one of the bad causes for the company, starting when the recording of receipts and disbursements in each month is not managed properly so that the position of the cash value cannot be known whether it is increasing or not. make a loss. With good and correct cash management, the benefits will be easier to identify before a crisis in cash finance occurs.

\section{Conclusion}

Based on the problems that have been discussed by the author regarding the liability payment system at PT. Indonesia Power PLTU Banten 2 Labuan OMU, the authors can draw conclusions, among others, as follows:

1. The liability payment system at PT. Indonesia Power PLTU Banten 2 Labuan OMU has explained in detail, such as the procedure for paying liabilities, the documents needed and must be prepared when paying liabilities to other parties, related functions, when paying liabilities at PT. Indonesia Power PLTU Banten 2 Labuan OMU there are several stages when paying liabilities, including vendors entering invoices, checking billing files, submitting invoices to ERP, checking taxes, submitting VAT \& PPH tax impositions, validating taxes and then submitting them to the finance department, Manager administration of verification and signature on the billing file, proof of cash out, making payments, posting in the ERP system and also the BNI bank application.

2. Constraints that occur at the time of payment of liabilities are not making a mature plan and poor cash management.

\section{Acknowledgment}

Acknowledgments are conveyed to the Diploma Three Accounting Study Program, Faculty of Economics and Business, University of Sultan Ageng Tirtayasa.

\section{References}

Mulyadi, 2016. Accounting System. Jakarta: Four Salemba.

Mulyadi, 2010. Accounting System. Jakarta: Salemba Empat

Romney et al, 2015. Accounting Information Systems. Jakarta: Salemba Empat

Soemarso, 2010. An Introduction to Accounting: Fourth Printing. Jakarta: Salemba Empat 
Ardana, Cenik and Hendro Lukman. 2016. Accounting Information System. Jakarta: Media Discourse Partners

Warren, et al. 2014. Introduction to Accounting 1 - Indonesian Adaptation of Empathy. Jakarta: Salemba Empat

Agoes, Sukrisno. 2013. Auditing: (Accountant Examination) by Public Accounting Firm Volume 1. Jakarta: Publishing Institute Faculty of Economics, University of Indonesia

Adriani Helen. 2019. Fixed Asset Internal Control System at PT. PIn (Persero) distribution Banten North Banten Area, University of Sultan Ageng Tirtayasa. 